Kredo 4 (2020)
KREDO: Jurnal Ilmiah Bahasa dan Sastra
Terakreditasi Sinta 4 berdasarkan Keputusan Direktorat
Jenderal Penguatan Riset dan Pengembangan,
Kementerian Riset, Teknologi dan Pendidikan Tinggi
Republik Indonesia
Nomor: 23/E/KPT/2019. 08 Agustus 2019
https://jurnal.umk.ac.id/index.php/kredo/index

\title{
TINGKAT MEMBACA PEMAHAMAN SISWA SMA KABUPATEN LAMONGAN
}

\author{
Abdul Kholiq ${ }^{1}$, Dian Luthfiyati ${ }^{2}$ \\ abdulkholiq@unisla.ac.id
}

Universitas Islam Lamongan, Indonesia

Info Artikel
Sejarah Artikel
Diterima
22 Juni 2019
Disetujui
24 Juni 2020
Dipublikasikan
28 Oktober 2020

Keywords

Keywords:

Reading

Comprehension,

Literal

Comprehension,

Inferential

Comprehension,

Critical

Comprehension,

creative

Comprehension

\section{Kata Kunci}

Membaca

Pemahaman,

Pemahaman Literal,

Pemahaman

Inferensial,

Pemahaman Kritis,

Pemahaman Kreatif
: $\quad$ Abstract

: $\quad$ The focus of this research is the level of reading comprehension of high school students in the Lamongan. This study uses a quantitative descriptive approach. This study uses a test sheet instrument of reading comprehension. The population of the study was all high school students in the Lamongan. The sampling method in this study is proportional sampling. The sample were 10 schools located in Lamongan, namely (1) SMAN 1 Mantup Lamongan; (2) SMAN 1 Paciran Lamongan; (3) SMAN 2 Lamongan; (4) Lamum Ulum High School Senior High School; (5) SMAN 1 Babat Lamongan; (6) SMAN 1 Bluluk Lamongan; (7) SMAN 1 Kembangbahu Lamongan; (8) SMA Nurul Huda Lamongan; (9) Lamongan Khozainul Ulum High School; (10) Nusantara High

: School Deket Lamongan. Each school is taken a sample of 30 students to fill the students' reading comprehension test. It can be said that the number of students tested in this study was 300 students. In collecting data this study used the test method. Analyzing research data is done by determining the average value of students. The benchmark reference assessment (PAP) used in this study was 60. From the results of the study, the average reading comprehension ability of high school students in Lamongan Regency was 48.62. If it is linked in the assessment scoring criteria in this study it can be stated that the reading ability of Lamongan Kabupatean High School students' comprehension is very low.

\begin{abstract}
Abstrak
Fokus penelitian ini adalah tingkat kemampuan membaca pemahaman siswa SMA se-Kabupaten Lamongan. Penelitian ini menggunakan pendekatan deskritif kuantitatif. Penelitian ini menggunakan instrumen lembar tes membaca pemahaman siswa. Populasi dari penelitian adalah seluruh siswa SMA se-Kabupaten Lamongan. Metode sampling dalam penelitian ini adalah proportional sampling dengan pengambilan sampel $10 \%$ dari populasi. Sampel dalam penelitian ini adalah 10 sekolah yang berada di Kabupaten Lamongan, yaitu (1) SMAN 1 Mantup Lamongan; (2) SMAN 1 Paciran Lamongan; (3) SMAN 2 Lamongan; (4) SMA Mazroatul Ulum Lamongan; (5) SMAN 1 Babat Lamongan; (6) SMAN 1 Bluluk Lamongan; (7) SMAN 1 Kembangbahu Lamongan; (8) SMA Nurul Huda Lamongan; (9) SMA Khozainul Ulum Lamongan; (10) SMA Nusantara Deket Lamongan. Setiap sekolah diambil sampel 30 siswa untuk mengisi tes membaca pemahaman siswa. Dapat dikatakan bahwa jumlah siswa yang diuji dalam penelitian ini adalah 300 siswa. Dalam pengumpulan data penelitian ini digunakan metode tes. Penganalisisan data penelitian dilakukan dengan penentuan rata-rata nilai siswa. Penilaian Acuan Patokan (PAP) yang digunakan pada penelitian ini adalah 60. Dari hasil penelitian, rata-rata kemampuan membaca pemahaman siswa SMA Kabupaten Lamongan adalah 48.62. Jika dikaitkan dalam kriteria penskoran penilaian dalam penelitian ini dapat dinyatakan bahwa kemampuan membaca pemahaman siswa SMA Kabupatean Lamongan adalah sangat rendah.
\end{abstract}




Kredo 4 (2020)
KREDO: Jurnal Ilmiah Bahasa dan Sastra
Terakreditasi Sinta 4 berdasarkan Keputusan Direktorat
Jenderal Penguatan Riset dan Pengembangan,
Kementerian Riset, Teknologi dan Pendidikan Tinggi
Republik Indonesia
Nomor: 23/E/KPT/2019. 08 Agustus 2019
https://jurnal.umk.ac.id/index.php/kredo/index

\section{PENDAHULUAN}

Tingkat literasi akan selalu berhubungan erat dengan kemampuan membaca siswa. Pengukuran tingkat literasi siswa dapat dilakukan dengan menganalisis tingkat kemampuan membaca dan menulis. Hal tersebut seiring dengan pengertian literasi adalah kemampuan mengakses, memahami, dan menggunakan sesuatu secara cerdas melalui berbagai aktivitas, antara lain membaca, melihat, menyimak, menulis, dan berbicara (Kemendikbud, 2016:2). Dari pengertian tersebut menunjukkan bahwa kemampuan membaca berhubungan erat dengan tingkat literasi siswa.

Dalam pengembangan keterampilan membaca juga terumuskan pada penyusunan silabus dan RPP, terdapat SK (standar kompetensi) dan KD (kompetensi dasar) yang harus dirumuskan guru pada tahap perencanaan pembelajaran. Rumusan standar kompetensi merupakan capaian akhir yang harus dipenuhi pada mata pelajaran tertentu (Supriono, 2014). Kata standar kompetensi berarti diartikan sebagai kompetensi akhir yang harus dikuasai siswa. Kata penting dalam rumusan tersebut adalah "kompetensi". Setelah mendapatkan materi tertentu, siswa diharapkan mampu menguasai suatu keterampilan yang mampu membekali siswa untuk mendapatkan nilai kognitif, afektif, dan psikomotor. Dalam pembelajaran bahasa kompetensikompetensi yang diharapkan dikuasai oleh siswa adalah kompetensi yang berupa kompetensi siswa dalam menyimak, membaca, berbicara, dan menulis. Keempat kompetensi itu disebut keterampilan berbahasa (Laila, 2009). Keempat keterampilan tersebut saling berkaitan antara satu dengan yang lain. Keterampilan menyimak seorang siswa dapat diukur melalui keterampilan berbicaranya atau keterampilan menulisnya. Begitu pun dengan keterampilan membaca.

Keterampilan membaca adalah proses pemahaman bahasa dalam ragam tulis. Proses pemahaman tersebut untuk memperoleh pengetahuan dan informasi dari suatu bacaan atau wacana tertentu dalam bentuk teks. Keterampilan membaca seorang siswa juga menentukan bagaimana pengetahuan dan kognitif siswa di pelajaran yang lain (Kholiq, 2018). Semakin bagus keterampilan membaca siswa semakin cepat mereka memahami bacaan yang diberikan guru pada mata pelajaran yang lain (Laila, 2009). Dari beberapa macam membaca, membaca pemahaman ditempatkan sebagai membaca pada tingkat tinggi karena membaca pemahaman berusaha mencari isi yang tersurat dan tersirat dari bacaan. Dalam pengukurannya, kemampuan membaca pemahaman siswa dapat dilihat setelah mereka memahami bacaan, baik dengan cara membuat ringkasan secara lisan atau tertulis maupun menjawab beberapa pertanyaan yang menguji pemahaman siswa atas bacaan (Sulikhah, Utomo, Santoso, 2020).

Dilihat dari tingkatannya, membaca pemahaman terdiri atas empat tingkat, yaitu (1) membaca pemahaman literal; (2) membaca pemahaman inferensial; (3) membaca pemahaman kritis; dan (4) membaca pemahaman kreatif (Laily, 2014). Keempat tingakatan tersebut menentukan bagaimana tinggi rendahnya

\section{8 | Jurnal Kredo}

Vol. 4 No. 1 Oktober 2020 


Kredo 4 (2020)
KREDO: Jurnal Ilmiah Bahasa dan Sastra
Terakreditasi Sinta 4 berdasarkan Keputusan Direktorat
Jenderal Penguatan Riset dan Pengembangan,
Kementerian Riset, Teknologi dan Pendidikan Tinggi
Republik Indonesia
Nomor: 23/E/KPT/2019. 08 Agustus 2019
https://jurnal.umk.ac.id/index.php/kredo/index

kemampuan membaca pemahaman siswa. Keempat tingkatan tersebut memiliki beberapa pengukuran tes yang berbeda-beda. Setiap tingkatan memiliki ciri pemahaman yang berbeda sehingga jenis pertanyaan tes untuk mengukurnya pun sudah dapat ditentukan pertanyaan pada masing-masing tingkatan yang akan diukur.

Tingkat membaca pemahaman literal diartikan sebagai tingkat membaca pemahaman yang mengukur bagaimana kemampuan siswa dalam memahami informasi tertulis/tersurat dari bacaan (Kholiq, 2018). Tingkat pemahaman literal berorientasi pada kemampuan analisis siswa dalam menangkap pemahaman dengan merujuk penggalan teks sebagai bukti dari pemahaman yang mereka peroleh. Tingkat membaca pemahaman literal merupakan tingkat membaca pemahaman yang yang paling rendah karena siswa dapat dengan mudah memperoleh pemahaman dari teks secara langsung tanpa analisis yang lebih mendalam. Jika dikaitkan dengan taksonomi Bloom (Gunawan dan Palupi, 2012) tingkat membaca pemahaman literal setingkat pada tataran mengingat (remember).

Tingkat membaca pemahaman inferensial diartikan sebagai tingkat membaca pemahaman siswa pada tataran memahami informasi secara tersirat. Siswa diminta berpikir satu tingkat di atas pemahaman literal. Jawaban dari pertanyaan pun dijawab oleh siswa berdasar atas teks, tetapi jawabannya belum tentu tertulis dalam teks. Tingkat membaca pemahaman inferensial setara dengan kemampuan siswa pada tingkat memahami (understanding) jika dikaitkan dengan rumusan dalam Taksonom Bloom.

Tingkat membaca pemahaman kritis diartikan sebagai tingkat membaca yang dimiliki oleh siswa pada tataran menilai keakuratan dan kebenaran informasi. Tingkat membaca pemahaman kritis sudah masuk dalam kemampuan berpikir tingkat tinggi. Siswa diminta untuk menilai informasi yang sesuai dan tidak sesuai dengan bacaan yang telah dibaca. Dari hal tersebut siswa berpikir berkalikali tentang kesesuaian informasi yang dengan bacaan. Selain itu, tingkat membaca pemahaman juga berkaitan dengan kemampuan siswa dalam menunjukkan kesalahan unsur bahasa (kata, frasa, klausa, kalimat) dan ejaan yang digunakan dalam bacaan. Jika dikaitkan dengan rumusan taksonomi Bloom, tingkat membaca mahaman kritis masuk dalam kemampuan evaluasi (evaluation).

Tingkat membaca pemahaman kreatif berkaitan dengan kemampuan siswa dalam menyusun unsur baru (ide, topik, kata, kalimat) dalam bacaan. Tingkat membaca pemahaman kreatif merupakan tingkat pemahaman yang paling tinggi dari keempat tingkat membaca pemahaman. Sesuai dengan rumusan taksonomi Bloom, tingkatan membaca pemahaman kreatif setara dengan kemampuan mencipta (creation). Kemampuan tersebut adalah kemampuan tertinggi yang dimiliki oleh siswa.

Tentunya membaca pemahaman menjadi keterampilan yang paling menentukan untuk kemampuan membaca siswa. Keterampilan membaca pemahaman mengantarkan siswa untuk memahami bacaan-bacaan di mata pelajaran yang lain. Jika seorang siswa 


Kredo 4 (2020)
KREDO: Jurnal Ilmiah Bahasa dan Sastra
Terakreditasi Sinta 4 berdasarkan Keputusan Direktorat
Jenderal Penguatan Riset dan Pengembangan,
Kementerian Riset, Teknologi dan Pendidikan Tinggi
Republik Indonesia
Nomor: 23/E/KPT/2019. 08 Agustus 2019
https://jurnal.umk.ac.id/index.php/kredo/index

memiliki keterampilan membaca pemahaman yang rendah, siswa tersebut akan sulit untuk memahami materi di mata pelajaran yang lain.

Akan tetapi, OECD (2019) menyatakan bahwa hasil dari Program for International Student Assessment (PISA), Indonesia menempati negara dengan urutan terakhir di bidang reading performance pada tahun 2018 dengan rata-rata 371. Pencapaian tersebut dapat dikatakan rendah dari negara-negara lain yang rata-rata pencapaiannya adalah 487. Perolehan Indonesia tersebut juga dikatakan di bawah rata-rata. Artinya, kemampuan membaca pemahamannya juga sangat rendah.

Hasil tersebut menunjukkan bahwa kemampuan membaca siswa Indonesia sangat rendah. Rendahnya kemampuan membaca tersebut dapat dipengaruhi oleh beberapa faktor, yaitu minat baca yang rendah, budaya baca yang rendah, kurikulum sekolah yang tidak berorientasi pada peningkatan minat baca siswa, dll. Banyak kalangan yang berpendapat bahwa perolehan tingkat membaca siswa Indonesia yang rendah tersebut disebabkan oleh tidak meratanya tingkat pendidikan di Indonesia. Ardika, Sitawati, \& Suciani, (2017) mengatakan bahwa pendidikan di luar Jawa yang masih tertinggal perlu mendapatkan perhatian agar tidak muncul kecemburuan sosial. Hal tersebut dimungkinkan menjadi penyebab rendahnya pendidikan di Indonesia. Atas dasar tersebut, sebenarnya diperlukan analisis tingkat pendidikan pada setiap daerah secara berkesinambungan (sustaintable) sehingga pemetaan tingkat pendidikan akan dapat dibentuk. Dengan terbentuknya pemetaan pendidikan tersebut, pengembangan rumusan rencana dirumuskan dengan berdasarkan kondisi daerah setempat.

Tentunya penelitian lebih lanjut harus dilakukan untuk memberikan kontribusi terhadap perbaikan kualitas pendidikan di Indonesia. Hal tersebut dapat dilakukan dengan melakukan penelitian tingkat membaca di tingkat daerah sebagai masukan untuk dinas pendidikan di tingkat daerah. Penelitian tingkat membaca pemahaman di tingkat daerah tersebut dapat dilakukan pada siswa SMA di Kabupaten Lamongan. Dari sisi pendidikan, Ketersediaan sarana pendidikan baik sarana maupun prasarana SMA di Lamongan sangat menunjang dalam meningkatkan pendidikan (BPS Lamongan, 2017). Dari data tersebut, dapat dikatakan bahwa kualitas layanan pendidikan di SMA di Lamongan sangat bagus dan akan berdampak pada keterampilan siswa SMA di Kabupaten lamongan.

Dari uraian di atas, penelitian ini difokuskan pada tingkat membaca pemahaman siswa SMA karena siswa SMA cenderung menguasai keempat tingkat pemahaman di atas. Dari hal tersebut, penelitian yang mengukur tentang tingkat membaca pemahaman di daerah Lamongan tentunya sangat efektif untuk mengetahui seberapa jauh tingkat membaca siswa di Lamongan sebagai dasar pemetaan tingkat membaca siswa Indonesia.

Dari uraian di atas, penelitian ini bertujuan untuk mengetahui bagaimana tingkat membaca pemahaman siswa SMA di Kabupaten Lamongan. Fokus penelitian ini adalah (1) tingkat membaca pemahaman literal; (2) tingkat

\section{0 | Jurnal Kredo}

Vol. 4 No. 1 Oktober 2020 


Kredo 4 (2020)
KREDO: Jurnal Ilmiah Bahasa dan Sastra
Terakreditasi Sinta 4 berdasarkan Keputusan Direktorat
Jenderal Penguatan Riset dan Pengembangan,
Kementerian Riset, Teknologi dan Pendidikan Tinggi
Republik Indonesia
Nomor: 23/E/KPT/2019. 08 Agustus 2019
https://jurnal.umk.ac.id/index.php/kredo/index

membaca pemahaman inferensial; (3) tingkat membaca pemahaman kritis; (4) tingkat membaca pemahaman kreatif siswa SMA di Kabupaten Lamongan.

\section{KAJIAN TEORI}

\section{Pengertian Membaca Pemahaman}

$\begin{array}{ccc}\text { Membaca adalah salah satu jenis } \\ \text { dari } & \text { keterampilan } & \text { membaca. }\end{array}$

Keterampilan membaca sendiri diartikan sebagai proses pemahaman bahasa dalam ragam tulis. Proses pemahaman tersebut untuk memperoleh pengetahuan dan informasi dari suatu bacaan atau wacana tertentu dalam bentuk teks. Kemampuan membaca dapat diartikan sebagai kemampuan dalam memahami bahan bacaan. Tujuan membaca adalah pemahaman bukan kecepatan (Tarigan, 1986:37).

Kholiq (2018) memperluas pengertian dari membaca pemahaman sebagai penelaahan bacaan kata demi kata menganalisis maksud dan tujuan penulisan bacaan tersebut dan mampu mengembangkannya ke dalam bacaan yang baru. Dilihat dari tingkatannya, membaca pemahaman terdiri atas empat tingkat, yaitu (1) membaca pemahaman literal; (2) membaca pemahaman inferensial; (3) membaca pemahaman kritis; dan (4) membaca pemahaman kreatif (Laily, 2014). Tingkatan tersebut merupakan klasifikasi kemampuan dalam membaca pemahaman. Tingkatan tersebut juga sejalan dengan taksonomi Bloom tentang tingkatan kognitif siswa.

Tarigan (1986: 13) menyatakan bahwa membaca pemahaman merupakan bagian dari membaca intensif yang tujuannya adalah memahami isi dari bacaan. Kemampuan membaca pemahaman merupakan kemampuan membaca di tingkat atas dibandingkan dengan kemampuan membaca yang lain. Hal tersebut menjadikan kemampuan membaca pemahaman dijadikan sebagai tolak ukur kemampuan reseptif seseorang.

\section{Tujuan Membaca Pemahaman \\ Somadayo (2011:}

menyampaikan bahwa tujuan dari membaca pemahaman adalah untuk memperoleh pemahaman. Sesorang dikatakan memiliki kemampuan membaca pemahamn dengan sangat baik ketika mampu (1) menangkap makna dari setiap kata dan istilah yang disampaikan oleh peneliti; (2) memahami makna implisit dan eksplisit dari kata atau kalimat yang digunakan penulis; (3) menemukan simpulan dari bacaan yang dipahami. Selain itu, membaca pemahaman juga dimaksudkan untuk menangkap ide yang disampaikan penulis, baik yang tertuang dalam bacaan maupun tidak. Bahkan, membaca pemahaman juga menjadi jembatan untuk menangkap arah pembicaraan penulis melalui bacaan yang dipahami.

Lebih jauh, Somadayo (2011:12) juga menyampaikan bahwa tujuan membaca pemahaman adalah untuk memahami isi bacaan dalam teks. Tujuan itu adalah (1) untuk memperoleh rincian-rincian dan fakta-fakta; (2) untuk mendapatkan ide pokok; (3) untuk mendapatkan urutan organisasi teks (4) untuk mendapatkan kesimpulan; (5) untuk mendapatkan klasifikasi (6) untuk membuat perbandingan atau pertentangan. Tarigan H.G. Tarigan (1986: 117) menambahkan bahwa tujuan dari membaca pemahaman adalah untuk 


Kredo 4 (2020)
KREDO: Jurnal Ilmiah Bahasa dan Sastra
Terakreditasi Sinta 4 berdasarkan Keputusan Direktorat
Jenderal Penguatan Riset dan Pengembangan,
Kementerian Riset, Teknologi dan Pendidikan Tinggi
Republik Indonesia
Nomor: 23/E/KPT/2019. 08 Agustus 2019
https://jurnal.umk.ac.id/index.php/kredo/index

menajawab beberapa pertanyaan tentang bacaan, seperti tema bacaan; pernyataanpernyataan dalam bacaan; proses pengembangan gagasan yang disampaikan penulis pada bacaan.

\section{Faktor yang Memengaruhi Proses Membaca Pemahaman}

Lamb dan Arnold

menyampaikan bahwa faktor yang memengaruhi proses membaca pemahaman terdiri atas beberapa macam, yaitu

1) Faktor Lingkungan, faktor lingkungan seorang pembaca memengaruhi proses membaca pemahaman. Faktor lingkungan tersebut meliputi kondisi di sekitar pembaca, seperti kondisi kelas, suasana tempat di sekitar pembaca, dan fasilitas yang tersedia saat proses membaca pemahaman berlangsung.

2) Faktor Intelektual, faktor intelektual berkaitan dengan kemampuan pembaca untuk memahamai bacaan. Factor ini sangat menentukan berhasil dan gagalnya proses membaca pemahaman. Seoarang yang memiliki intelektual yang rendah akan mengalami kesulitan dalam proses membaca pemahaman. Begitu pula sebaliknya pada seorang yang memiliki intelektual yang tinggi.

3) Faktor psikologis, factor psikologis berkaitan dengan motivasi dan minat pembaca. Selain itu, factor pesikologis juga berkaitan dengan tingkat ketenangan pembaca dalam proses membaca pemahaman.

4) Factor fisiologis, factor fisiologis berkaitan dengan kenormalan alat-

22 | Jurnal Kredo Vol. 4 No. 1 Oktober 2020 alat tubuh pembaca dalam membaca. Misalnya, seorang yang mengalami gangguan pada indera penglihatan akan terganggu dalam proses membaca pemahaman.

\section{Tingkatan Membaca Pemahaman}

Terdapat beberapa tingkatan dalam membaca pemahaman. Tingkatan membaca pemahaman terdiri atas pemahaman literal, pemahaman inferensial, pemahaman kritis, dan pemahaman kreatif (Burns dalam Hairuddin dkk, 2008). Menurut Muis (2013:279), keempat tingkat pemahaman tersebut dijelaskan sebagai berikut.

a. Pemahaman literal adalah kemampuan untuk memahami teks yang tersurat. Tingkat pemahaman literal merupakan tingkat pemahaman yang terendah dalam tingkat membaca pemahaman. Pada tingkatan ini pembaca hanya memahami isi informasi bacaan secara tekstual dan tidak diperlukan pemahaman yang mendalam untuk menangkap ide bacaan yang disampaikan. Dalam pemahaman literal, pembaca akan mampu memahami bacaan dengan jawaban yang dasarnya sudah tertulis dalam bacaan. Pemahaman literal diperoleh dengan membaca apa yang dinyatakan secara langsung dalam teks bacaan

b. Pemahaman Inferensial adalah membaca setiap kata demi kata, kalimat demi kalimat untuk menemukan gagasan yang ingin disampaikan penulis. Muis (2013:279) menjelaskan bahwa pemahaman inferensial merupakan pemahaman dalam menangkan 


Kredo 4 (2020)
KREDO: Jurnal Ilmiah Bahasa dan Sastra
Terakreditasi Sinta 4 berdasarkan Keputusan Direktorat
Jenderal Penguatan Riset dan Pengembangan,
Kementerian Riset, Teknologi dan Pendidikan Tinggi
Republik Indonesia
Nomor: 23/E/KPT/2019. 08 Agustus 2019
https://jurnal.umk.ac.id/index.php/kredo/index

gagasan yang disampaikan secara tidak langsung. Pemahaman inferensial meliputi pembuatan simpulan, seperti tema bacaan, koherensi kalimat dan paragraf, penalaran bacaan, penginterpretasian bahasa figuratif. pemahaman inferensial menuntut pembaca untuk berpikir tingkat tinggi karena dalam pemahaman inferensial pembaca harus mampu menangkap apa yang sebenarna penulis inginkan dan pemahaman inferensial juga berkaitan tentang pemahaman yang tidak langsung ada pada teks.

c. Pemahaman kritis merupakan tingkat pemahaman yang melibatkan evaluasi, penilaian pribadi, dan kebenaran apa yang dibaca. Pemahaman kritis menuntut pembaca menganalisis bacaan dengan mengamati kata dan kalimat kunci untuk dapat dapat melakukan evaluasi terhadap bacaan. Pemahaman kritis berkaitan dengan penilaian kerensi paragraf, penggunaan kata dan kalimat yang kurang tepat, dan penentuan hubungan sebab akibat dari gagasan satu dengan gagasan yang lain.

d. Pemahaman kreatif adalah pemahaman dengan melibatkan kemampuan logika, estetika dan seni. Pemahaman kreatif menuntut kemampuan pembaca dalam hal logika untuk memahami bacaan, lalu menerka atau membuat gagasan yang relevan dengan bacaan yang telah dipahami. Bukan hanya logika dalam pemahaman kreatif, melainkan juga estetika dan seni dalam merangkai gagasan lanjutan dari sebuah bacaan. Pemahaman kreatif merupakan tingkat pemahaman yang paling tinggi dalam membaca pemahaman. Pemahaman ini biasanya dikuasi oleh penulis dan pembaca yang sudah ahli atau sudah lama berkecimpung dalam duniamembaca dan menulis.

Penelitian tentang membaca pemahaman biasanya akan mengacu pada keempat tingkatan pemahaman di atas. Membaca pemahaman dapat dianalisis dan dapat dikaji jika menguraikan keempat tinggkatan tersebut. Terdapat juga penelitian yang hanya mengambil variabel dari satu tingkatan pemahaman. Misalnya, penelitian tentang pemahaman literal siswa atau penelitian tentang tingkat membaca kritis siswa.

\section{Indikator Kemampuan Membaca Pemahaman}

Menurut Somadayo (2011:11) indikator membaca pemahaman meliputi 1) kemampuan menangkap arti kata dan ungkapan yang digunakan penulis; 2) kemampuan menangkap makna tersurat dan makna tersirat; dan 3) kemampuan membuat kesimpulan. Jika dikaitkan dengan penelitian ini, seorang pembaca dikatakan memiliki kemampuan dalam membaca pemahaman ketika memiliki keempat pemahaman membaca yang telah disampaikan pada pembahasan sebelumnya.

\section{METODE PENELITIAN}

Penelitian ini adalah penelitian deskriptif kuantitatif (Arikunto, 2010). 


Kredo 4 (2020)
KREDO: Jurnal Ilmiah Bahasa dan Sastra
Terakreditasi Sinta 4 berdasarkan Keputusan Direktorat
Jenderal Penguatan Riset dan Pengembangan,
Kementerian Riset, Teknologi dan Pendidikan Tinggi
Republik Indonesia
Nomor: 23/E/KPT/2019. 08 Agustus 2019
https://jurnal.umk.ac.id/index.php/kredo/index

Populasi penelitian adalah seluruh siswa SMA di Kabupaten Lamongan. Penelitian ini menggunakan proportional sampling dalam penentuan sampel penelitian. Sampel dalam penelitian ini adalah 10 SMA yang berada di Kabupaten Lamongan, yaitu (1) SMAN 1 Mantup Lamongan; (2) SMAN 1 Paciran Lamongan; (3) SMAN 2 Lamongan; (4) SMA Mazroatul Ulum Lamongan; (5) SMAN 1 Babat Lamongan; (6) SMAN 1 Bluluk Lamongan; (7) SMAN 1 Kembangbahu Lamongan; (8) SMA Nurul Huda Lamongan; (9) SMA Khozainul Ulum Lamongan; (10) SMA Nusantara Deket Lamongan. Setiap sekolah diambil sampel 30 siswa untuk mengisi tes membaca pemahaman siswa. Dapat dikatakan bahwa jumlah siswa yang diuji dalam penelitian ini adalah 300 siswa.

Pengumpulan data penelitian menggunakan tes. Setiap lembar tes berisikan bacaan dan soal yang menguji empat tingkatan membaca siswa. Setiap tes terdiri atas empat bacaan yang setiap bacaan terdiri atas sepuluh pertanyaan. Pertanyaan yang menguji pemahaman literal, inferensial, kritis, dan kreatif tersebar dalam setiap sepuluh pertanyaan dalam setiap bacaan.

Analisis data penelitian dengan menghitung rata-rata (mean) nilai siswa pada setiap tingkatan. Dalam penyajiannya, persentase rata-rata disampaikan pada analisis data. Penentuan kriteria dalam penelitian ini menggunakan penilaian acuan patokan (PAP) dengan PAP adalah 60 (Nurgiyantoro, 2001:397). Penentuan kriteria dengan PAP 60 tersebut dijabarkan pada tabel berikut.
Tabel 1 Penentuan kriteria tingkat membaca pemahaman siswa SMA di Kabupaten Lamongan

\begin{tabular}{cc}
\hline Rentang nilai & Kriteria \\
\hline $0-49$ & Sangat Rendah \\
\hline $50-59,99$ & Rendah \\
\hline $60-69,99$ & Sedang \\
\hline $70-79,99$ & Tinggi \\
\hline & Diadaptasi dari Nurgiyantoro (2001)
\end{tabular}

\section{HASIL DAN PEMBAHASAN}

\section{Tingkat Membaca Pemahaman Literal Siswa SMA Kabupaten Lamongan}

Dalam intrumen soal membaca pemahaman yang diberikan pada 300 siswa SMA di Kabupaten Lamongan terbagi atas menanyakan 4 aspek keterampilan membaca pemahaman siswa, yaitu tingkat membaca literal, inferensial, kritis, dan kreatif. Tingkat membaca pemahaman literal dalam instrument yang diberikan terdapat pada soal nomor 1, 2, 6, 11, 12, 21, 23, 31, 32, 33. Dari 10 soal tersebut,

Pada tingkat membaca pemahaman literal, siswa SMA Kabupaten Lamongan analisis utama dari penelitian ini adalah penentuan rata-rata nilai perolehan siswa. Perolehan nilai rata-rata nilai yang diperoleh siswa di setiap sekolah disajikan pada tabel berikut. (1=SMAN 1 Mantup Lamongan; 2=SMAN 1 Paciran Lamongan; 3=SMAN 2 Lamongan; 4=SMA Mazroatul Ulum Lamongan; 5=SMAN 1 Babat Lamongan; 6=SMAN 1 Bluluk Lamongan; 7=SMAN 1 Kembangbahu Lamongan; 8= SMA Nurul Huda Lamongan; 9=SMA Khozainul Ulum Lamongan; 10=SMA Nusantara Deket Lamongan) 


Kredo 4 (2020)
KREDO: Jurnal Ilmiah Bahasa dan Sastra
Terakreditasi Sinta 4 berdasarkan Keputusan Direktorat
Jenderal Penguatan Riset dan Pengembangan,
Kementerian Riset, Teknologi dan Pendidikan Tinggi
Republik Indonesia
Nomor: 23/E/KPT/2019. 08 Agustus 2019
https://jurnal.umk.ac.id/index.php/kredo/index

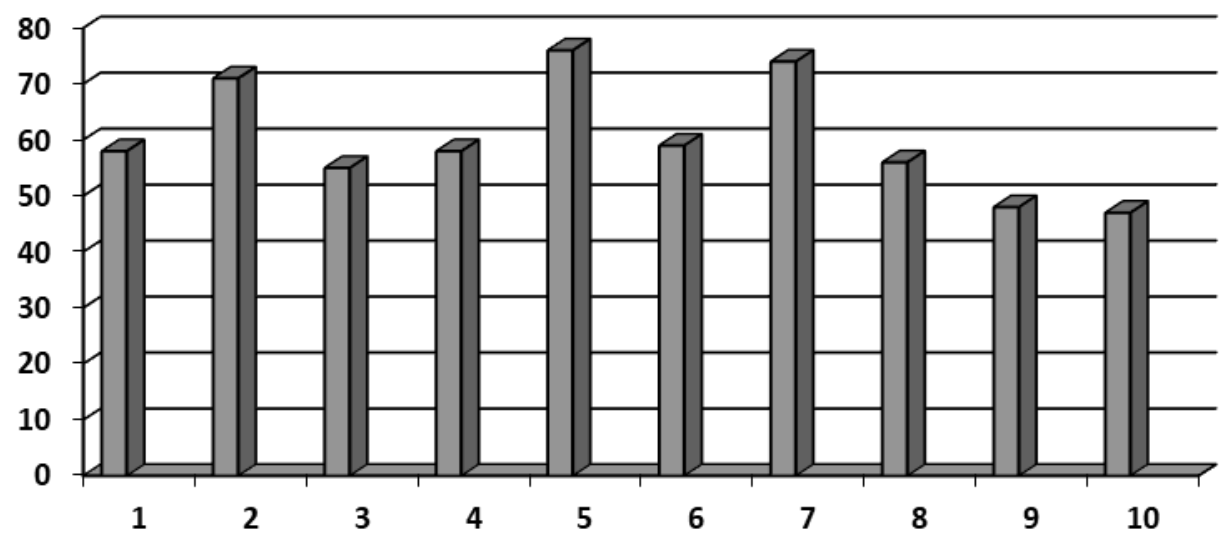

Bagan 1 Perolehan Rata-rata nilai Tingkat Pemahaman Literal Siswa SMA Kabupaten Lamongan

Dari bagan di atas, terlihat bahwa rata-rata perolehan nilai di atas nilai 50 . Untuk lebih jelasnya, perolehan rata-rata keseluruhan tingkat membaca pemahaman literal siswa SMA Kabupetan Lamongan dapat dilihat pada tabel berikut.

Tabel 2 Perolehan Rata-rata nilai Tingkat Pemahaman Literal Siswa SMA Kabupaten Lamongan

\begin{tabular}{ccc}
\hline No & Sekolah & $\begin{array}{c}\text { Rata- } \\
\text { rata }\end{array}$ \\
\hline 1 & SMAN 1 Mantup Lamongan & 58 \\
2 & SMAN 1 Paciran Lamongan & 71 \\
3 & SMAN 2 Lamongan & 55 \\
4 & SMA Mazroatul Ulum Lamongan & 58 \\
5 & SMAN 1 Babat Lamongan & 76 \\
6 & SMAN 1 Bluluk Lamongan & 59 \\
7 & SMAN 1 Kembangbahu Lamongan & 74 \\
8 & SMA Nurul Huda Lamongan & 56 \\
9 & SMA Khozainul Ulum Lamongan & 48 \\
10 & SMA Nusantara Deket Lamongan & 47 \\
\hline \multicolumn{3}{c}{ Rata-rata } \\
\hline
\end{tabular}

Dari tabel di atas, perolehan nilai rata-rata pemahaman literal siswa SMA di Kabupaten Lamongan sebesar 60,2. Jika disesuaikan pada PAP (60) yang telah ditentukan, perolehan nilai rata-rata tingkat membaca pemahaman literal siswa SMA Kabupetan Lamongan dapat dikatakan tinggi. Nilai minimum adalah sebesar 47 dan nilai tertinggi adalah 76 . Dengan rentang tersebut dapat dimungkinkan bahwa paling tinggi siswa SMA di Kabupaten Lamongan akan mendapatkan nilai paling tinggi 76 . Hal tersebut memungkinkan untuk kebiasaan membaca SMA di Kabupaten Lamongan perlu ditingkatkan.

Dari Hasil perolehan rata-rata tingkat pemahaman literal SMA di Kabupaten Lamongan tersebut harusnya lebih tinggi lagi karena pemahaman literal adalah tingkat yang paling rendah. Akan tetapi, dengan perolehan rata-rata sebesar 60,2 membuat tingkat pemahaman literal siswa SMA di Kabupaten Lamongan hanya sebatas memahami, tidak lebih. Jika pemahaman literal siswa 60,2, dapat dimungkinkan untuk pemahaman yang lebih tinggi nilai yang didapatkan semakin rendah.

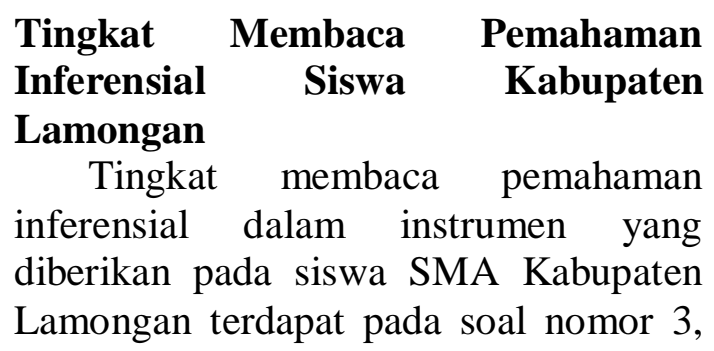




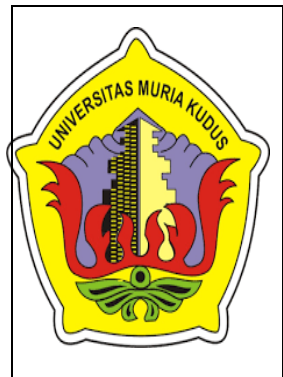

Kredo 4 (2020)

KREDO: Jurnal Ilmiah Bahasa dan Sastra

Terakreditasi Sinta 4 berdasarkan Keputusan Direktorat Jenderal Penguatan Riset dan Pengembangan,

Kementerian Riset, Teknologi dan Pendidikan Tinggi

Republik Indonesia

Nomor: 23/E/KPT/2019. 08 Agustus 2019

https://jurnal.umk.ac.id/index.php/kredo/index

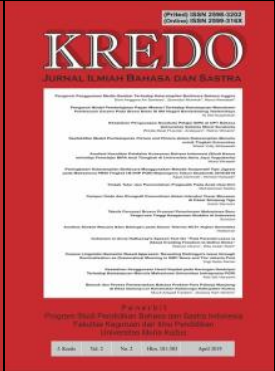

$5,8,13,16,22,24,34,35,36$. Pada tingkat membaca pemahaman inferensial, siswa SMA Kabupaten Lamongan analisis utama dari penelitian ini adalah penentuan rata-rata nilai perolehan siswa. Perolehan nilai rata-rata nilai yang diperoleh siswa di setiap sekolah disajikan pada tabel berikut. (1=SMAN 1 Mantup Lamongan;
2=SMAN 1 Paciran Lamongan; $3=$ SMAN 2 Lamongan; 4=SMA Mazroatul Ulum Lamongan; 5=SMAN 1 Babat Lamongan; 6=SMAN 1 Bluluk Lamongan; 7=SMAN 1 Kembangbahu Lamongan; 8= SMA Nurul Huda Lamongan; 9=SMA Khozainul Ulum Lamongan; 10=SMA Nusantara Deket Lamongan)

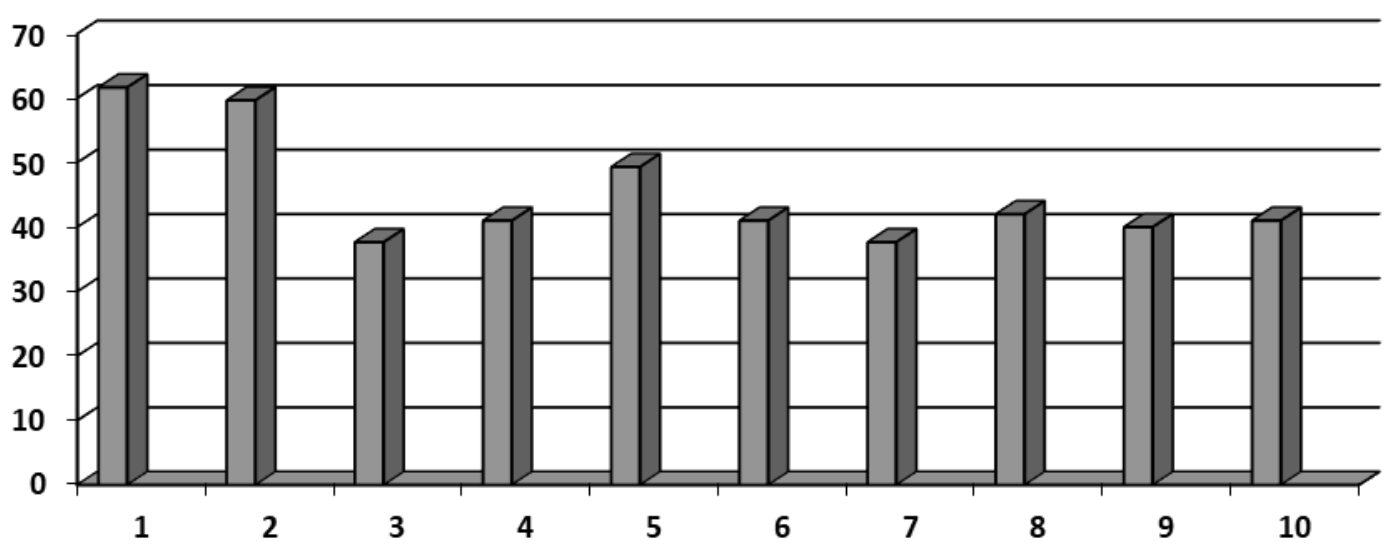

Bagan 2 Perolehan Rata-rata nilai Tingkat Pemahaman Inferensial Siswa SMA Kabupaten Lamongan

Dari bagan di atas, terlihat bahwa rata-rata perolehan nilai ada yang di atas 60 (nilai PAP) dan ada yang di bawahnya. Untuk lebih jelasnya, perolehan rata-rata keseluruhan tingkat membaca pemahaman inferensial siswa SMA Kabupetan Lamongan dapat dilihat pada tabel berikut.

Tabel 3 Perolehan Rata-rata nilai Tingkat Pemahaman inferensial Siswa SMA Kabupaten Lamongan

\begin{tabular}{ccc}
\hline No & Sekolah & $\begin{array}{c}\text { Rata- } \\
\text { rata }\end{array}$ \\
\hline 1 & SMAN 1 Mantup Lamongan & 61.66 \\
2 & SMAN 1 Paciran Lamongan & 59.66 \\
3 & SMAN 2 Lamongan & 37.66 \\
4 & SMA Mazroatul Ulum Lamongan & 41 \\
5 & SMAN 1 Babat Lamongan & 49.33 \\
6 & SMAN 1 Bluluk Lamongan & 41 \\
7 & SMAN 1 Kembangbahu Lamongan & 37.66 \\
\hline $\mathbf{2 6}$ & I Jurnal Kredlo & \\
& Vol. 4 No. 1 Oktober 2020
\end{tabular}

\begin{tabular}{ccc}
\hline 8 & SMA Nurul Huda Lamongan & 42 \\
9 & SMA Khozainul Ulum Lamongan & 40 \\
10 & SMA Nusantara Deket Lamongan & 41 \\
\hline Rata-rata & 45,09 \\
\hline
\end{tabular}

Dari tabel di atas, terlihat bahwa rata-rata kemampuan membaca pemahaman inferensial siswa SMA Kabupaten Lamongan adalah 46.85. Jika dikaitkan dalam kriteria penskoran penilaian dalam penelitian ini dapat dinyatakan bahwa kemampuan membaca pemahaman inferensial siswa SMA Kabupatean Lamongan adalah sangat rendah.

Dari tabel di atas, nilai tertinggi pada pemahaman inferensial siswa SMA di Kabupaten Lamongan adalah sebesar 


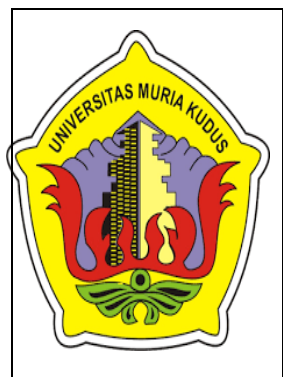

Kredo 4 (2020)

KREDO: Jurnal Ilmiah Bahasa dan Sastra

Terakreditasi Sinta 4 berdasarkan Keputusan Direktorat Jenderal Penguatan Riset dan Pengembangan,

Kementerian Riset, Teknologi dan Pendidikan Tinggi

Republik Indonesia

Nomor: 23/E/KPT/2019. 08 Agustus 2019

https://jurnal.umk.ac.id/index.php/kredo/index

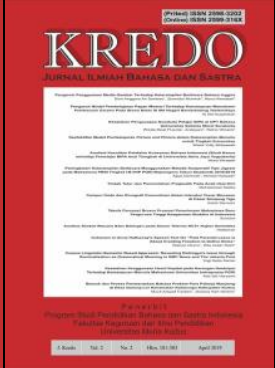

61,66 dan terendah adalah sebesar 37,66.

Hal tersebut menunjukkan bahwa kemampuan pemahaman inferensial siswa SMA di Kabupaten Lamongan adalah sangat rendah. hal tersebut juga menunjukkan rendahnya kualitas membaca siswa SMA di Kabupaten Lamongan.

\section{Tingkat Membaca Pemahaman Kritis Siswa Kabupaten Lamongan}

Tingkat membaca pemahaman kritis dalam instrumen yang diberikan pada siswa SMAN 1 Bluluk terdapat pada soal nomor 7, 9, 14, 17, 18, 25, 27, 28, 37, 38. Pada tingkat membaca pemahaman kritis, siswa SMA Kabupaten Lamongan analisis utama dari penelitian ini adalah penentuan ratarata nilai perolehan siswa. Perolehan nilai rata-rata nilai yang diperoleh siswa di setiap sekolah disajikan pada tabel berikut. (1=SMAN 1 Mantup Lamongan; 2=SMAN 1 Paciran Lamongan; $3=$ SMAN 2 Lamongan; 4=SMA Mazroatul Ulum Lamongan; 5=SMAN 1 Babat Lamongan; 6=SMAN 1 Bluluk Lamongan; 7=SMAN 1 Kembangbahu Lamongan; 8= SMA Nurul Huda Lamongan; 9=SMA Khozainul Ulum Lamongan; 10=SMA Nusantara Deket Lamongan

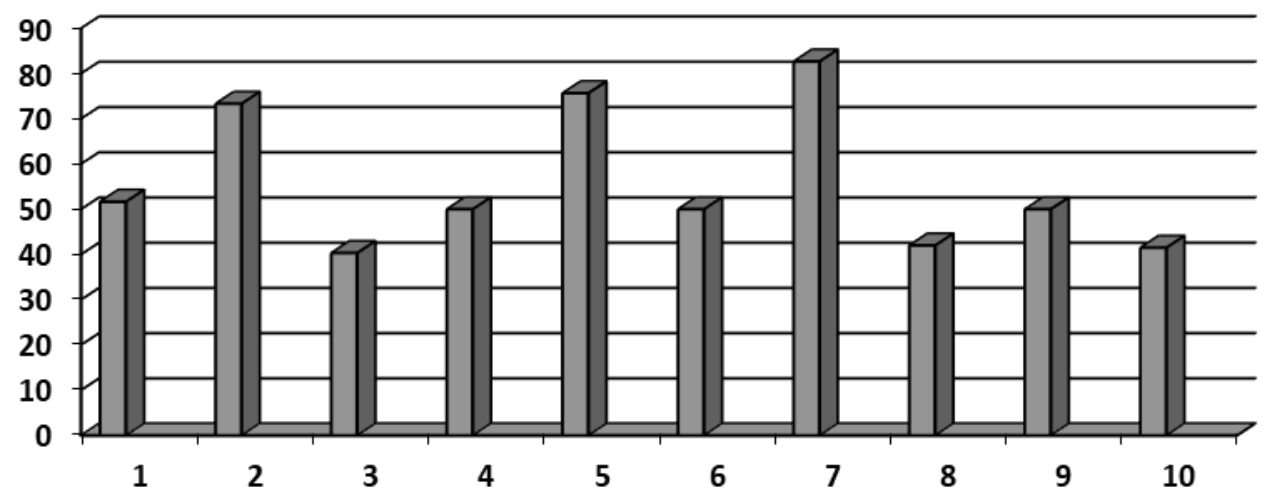

Bagan 3 Perolehan Rata-rata nilai Tingkat Pemahaman Kritis Siswa SMA Kabupaten Lamongan

Dari bagan di atas, terlihat bahwa rata-rata perolehan nilai ada yang di atas 60 (nilai PAP) dan ada yang di bawahnya. Untuk lebih jelasnya, perolehan rata-rata keseluruhan tingkat membaca pemahaman kritis siswa SMA Kabupetan Lamongan dapat dilihat pada tabel berikut.

Tabel 4 Perolehan Rata-rata nilai Tingkat Pemahaman Kritis Siswa SMA Kabupaten Lamongan No Sekolah Rata-

\begin{tabular}{lll}
\hline & & rata \\
\hline 1 & SMAN 1 Mantup Lamongan & 51.66 \\
2 & SMAN 1 Paciran Lamongan & 73,33 \\
3 & SMAN 2 Lamongan & 40,33 \\
4 & SMA Mazroatul Ulum Lamongan & 50 \\
5 & SMAN 1 Babat Lamongan & 75,66 \\
6 & SMAN 1 Bluluk Lamongan & 50 \\
7 & SMAN 1 Kembangbahu Lamongan & 82,66 \\
8 & SMA Nurul Huda Lamongan & 42 \\
9 & SMA Khozainul Ulum Lamongan & 50 \\
10 & SMA Nusantara Deket Lamongan & 41,5 \\
\hline Rata-rata & 55.71 \\
\hline
\end{tabular}

Dari tabel di atas, terlihat bahwa rata-rata kemampuan membaca pemahaman kritis siswa SMA 


\begin{tabular}{|c|c|c|} 
Kredo 4 (2020) \\
KREDO: Jurnal Ilmiah Bahasa dan Sastra \\
Terakreditasi Sinta 4 berdasarkan Keputusan Direktorat \\
Jenderal Penguatan Riset dan Pengembangan, \\
Kementerian Riset, Teknologi dan Pendidikan Tinggi \\
Republik Indonesia \\
Nomor: 23/E/KPT/2019. 08 Agustus 2019 \\
https://jurnal.umk.ac.id/index.php/kredo/index
\end{tabular}

Kabupaten Lamongan adalah 50.55. Jika dikaitkan dalam kriteria penskoran penilaian dalam penelitian ini dapat dinyatakan bahwa kemampuan membaca pemahaman kritis siswa SMA Kabupatean Lamongan adalah sedang.

Dari tabel di atas, nilai tertinggi pada pemahaman kritis siswa SMA di Kabupaten Lamongan adalah sebesar 73,33 dan terendah adalah sebesar 40,33. Hal tersebut menunjukkan bahwa kemampuan pemahaman kritis siswa SMA di Kabupaten Lamongan adalah sangat rendah. Hal tersebut juga menunjukkan rendahnya kualitas membaca siswa SMA di Kabupaten Lamongan.

Terdapat hal yang menarik dari hasil rata-rata perolehan nilai pemahaman kritis siswa SMA di Kabupaten Lamongan. Pada perolehan hasil tingkat pemahaman inferensial didapatkan bahwa pemhaman inferensial siswa sangat rendah, tetapi pada pemahaman kritis malah menjadi lebih baik. Hal tersebut menunjukkan bahwa siswa lebih bisa menganalisis dan mengevaluasi bacaan daripada memahaminya. Oleh karena itu, dibutuhkan penelitian lebih lanjut hubungan antara pemahaman inferensial dengan pemahaman kritis.

\section{Tingkat Membaca Pemahaman Kreatif Siswa Kabupaten Lamongan}

Tingkat membaca pemahaman kreatif dalam instrumen yang diberikan pada siswa SMAN 1 Bluluk terdapat pada soal nomor 4, 10, 15, 19, 20, 26,
29, 30, 39, 40. Pada tingkat membaca pemahaman kreatif, siswa SMA Kabupaten Lamongan analisis utama dari penelitian ini adalah penentuan ratarata nilai perolehan siswa. Perolehan nilai rata-rata nilai yang diperoleh siswa di setiap sekolah disajikan pada tabel berikut. (1=SMAN 1 Mantup Lamongan; 2=SMAN 1 Paciran Lamongan; $3=$ SMAN 2 Lamongan; 4=SMA Mazroatul Ulum Lamongan; 5=SMAN 1 Babat Lamongan; 6=SMAN 1 Bluluk Lamongan; 7=SMAN 1 Kembangbahu Lamongan)

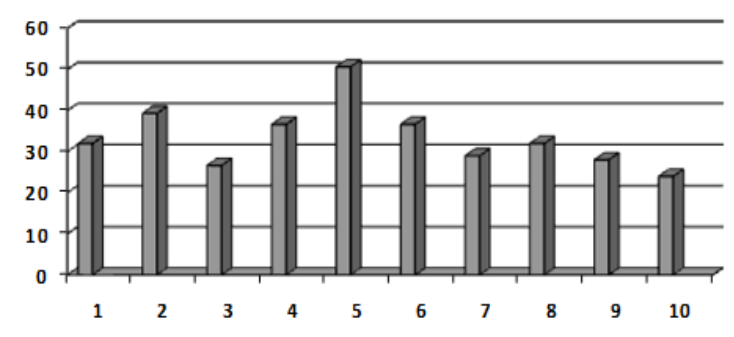

Bagan 4 Perolehan Rata-rata nilai Tingkat Pemahaman Kreatif Siswa SMA Kabupaten Lamongan

Dari bagan di atas, terlihat bahwa rata-rata perolehan nilai ada yang di atas 60 (nilai PAP) dan ada yang di bawahnya. Untuk lebih jelasnya, perolehan rata-rata keseluruhan tingkat membaca pemahaman kreatif siswa SMA Kabupetan Lamongan dapat dilihat pada tabel berikut. 


Kredo 4 (2020)
KREDO: Jurnal Ilmiah Bahasa dan Sastra
Terakreditasi Sinta 4 berdasarkan Keputusan Direktorat
Jenderal Penguatan Riset dan Pengembangan,
Kementerian Riset, Teknologi dan Pendidikan Tinggi
Republik Indonesia
Nomor: 23/E/KPT/2019. 08 Agustus 2019
https://jurnal.umk.ac.id/index.php/kredo/index

Tabel 5 Perolehan Rata-rata nilai Tingkat Pemahaman Kreatif Siswa SMA Kabupaten Lamongan

\begin{tabular}{ccc}
\hline No & Sekolah & $\begin{array}{c}\text { Rata- } \\
\text { rata }\end{array}$ \\
\hline 1 & SMAN 1 Mantup Lamongan & 32 \\
2 & SMAN 1 Paciran Lamongan & 39.33 \\
3 & SMAN 2 Lamongan & 26.67 \\
& & 36.67 \\
4 & SMA Mazroatul Ulum Lamongan & 50.67 \\
5 & SMAN 1 Babat Lamongan & 36.67 \\
6 & SMAN 1 Bluluk Lamongan & 29 \\
7 & SMAN 1 Kembangbahu Lamongan & 32 \\
8 & SMA Nurul Huda Lamongan & 28 \\
9 & SMA Khozainul Ulum Lamongan & 24 \\
10 & SMA Nusantara Deket Lamongan & 33.5 \\
\hline \multicolumn{3}{c}{ Rata-rata }
\end{tabular}

Dari tabel di atas, terlihat bahwa rata-rata kemampuan membaca pemahaman kreatif siswa SMA Kabupaten Lamongan adalah 35.85. Jika dikaitkan dalam kriteria penskoran penilaian dalam penelitian ini dapat dinyatakan bahwa kemampuan membaca pemahaman kreatif siswa SMA Kabupatean Lamongan adalah sangat rendah.

Dari tabel di atas, nilai tertinggi pada pemahaman kreatif siswa SMA di Kabupaten Lamongan adalah sebesar 50,67 dan terendah adalah sebesar 24 . Hal tersebut menunjukkan bahwa kemampuan pemahaman kreatif siswa SMA di Kabupaten Lamongan adalah sangat rendah. Hal tersebut juga menunjukkan rendahnya kualitas membaca siswa SMA di Kabupaten Lamongan.

Pada hasil tersebut, tingkat pemahaman kreatif siswa SMA di Kabupaten Lamongan adalah yang paling rendah. secara tidak langsung kemampuan siswa dalam berkreasi juga sangat rendah. Oleh karena itu, hal tersebut harusnya menjadi perhatian yang sangat serius bagi pemerintah daerah.

\section{PEMBAHASAN}

Dari hasil penelitian di atas dapat analisis penelitian ini dapat disajikan pada bagan di bawah ini.

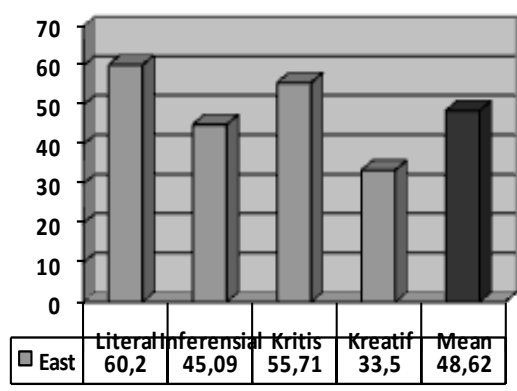

Bagan 5 Perolehan Rata-rata perolehan nilai membaca pemahaman

Dari bagan di atas, terlihat bahwa rata-rata perolehan nilai ada yang di atas 60 (nilai PAP) dan ada yang di bawahnya. Untuk lebih jelasnya, perolehan rata-rata keseluruhan tingkat membaca pemahaman siswa SMA Kabupetan Lamongan dapat dilihat pada tabel berikut.

Tabel 6 Perolehan Rata-rata perolehan nilai membaca pemahaman

\begin{tabular}{ccc}
\hline Nomor & $\begin{array}{c}\text { Tingkat Membaca } \\
\text { Pemahaman }\end{array}$ & $\begin{array}{c}\text { Rata- } \\
\text { rata }\end{array}$ \\
\hline 1 & Literal & 60.2 \\
2 & Inferensial & 45.09 \\
3 & Kritis & 55.71 \\
4 & Kreatif & 33.5 \\
\hline & Rata-rata & 48.62 \\
\hline
\end{tabular}

Dari tabel di atas, terlihat bahwa rata-rata kemampuan membaca pemahaman siswa SMA Kabupaten Lamongan adalah 48.62. Jika dikaitkan dalam kriteria penskoran penilaian dalam penelitian ini dapat dinyatakan 


Kredo 4 (2020)
KREDO: Jurnal Ilmiah Bahasa dan Sastra
Terakreditasi Sinta 4 berdasarkan Keputusan Direktorat
Jenderal Penguatan Riset dan Pengembangan,
Kementerian Riset, Teknologi dan Pendidikan Tinggi
Republik Indonesia
Nomor: 23/E/KPT/2019. 08 Agustus 2019
https://jurnal.umk.ac.id/index.php/kredo/index

bahwa kemampuan membaca pemahaman siswa SMA Kabupatean Lamongan adalah sangat rendah.

Dari hasil di atas, hasil penelitian PISA dinyatakan bahwa membaca siswa Indonesia di urutan ke 57 dari 65 negara yang diteliti dapat dipertanggungjawabkan. Buktinya, hasil penelitian ini pun menyatakan bahwa tingkat membaca siswa SMA di Kabupaten Lamongan sangat rendah. Perolehan tersebut menjadi peringatakan bagi pemerintah daerah Kabupaten Lamongan, khususnya Dinas Pendidikan Kabupetan Lamongan, untuk meningkatkan kemampuan membaca siswa. Selain itu, pihak sekolah, khususnya kepala sekolah, juga memiliki pekerjaan tambahan untuk meningkatkan kemampuan membaca siswa.

Dari hasil penelitian tersebut dapat ditarik akar masalahnya adalah kebiasaan membaca yang masih belum tertanam pada diri siswa. Seperti yang telah disampaikan oleh Lamb dan Arnol (dalam Somadayo (2011:27) yang menyampaikan bahwa faktor yang memengaruhi proses membaca pemahaman terdiri atas (1) faktor lingkungan; (2) faktor intelektual; (3) factor psikologis; (4) faktor fisiologis. Jika melihat kualitas siswa SMA di Kabupaten Lamongan yang mampu meraih juara dalam beberapa kompetisi akademik dan nonakademik, factor yang sangat memengaruhi rendahnya tingkat membaca siswa adalah factor psikologis.

Siswa SMA di Kabupaten Lamongan memiliki kompetensi yang bagus dalam berpikir tingkat tinggi, tetapi pada bidang saintifik. Akan tetapi, siswa SMA memiliki minat yang rendah pada pelajaran bahasa sehingga minta membaca pun terpengaruh untuk menjadi rendah. rendahnya minat baca tersebut memengaruhi kemampuan membaca mereka menjadi rendah. hal tersebut terlihat pada hasil penelitian ini.

\section{SIMPULAN}

Simpulan yang didapat dari penelitian ini adalah

a. Tingkat membaca pemahaman literal siswa SMA Kabupaten Lamongan dinyatakan sedang dengan perolehan rata-rata nilai 60,2 yang apabila dikaitkan pada penentuan kriteria rata-rata nilai dari PAP dapat dikatakan bahwa tingkat membaca pemahaman literal siswa SMA Kabupaten Lamongan adalah sedang.

b. Tingkat membaca pemahaman inferensial siswa SMA Kabupaten Lamongan dinyatakan sangat rendah dengan perolehan rata-rata nilai 45,09 yang apabila dikaitkan pada penentuan kriteria rata-rata nilai dari PAP dapat dikatakan bahwa tingkat membaca pemahaman inferensial siswa SMA Kabupaten Lamongan adalah sangat rendah.

c. Tingkat membaca pemahaman kritis siswa SMA Kabupaten Lamongan dinyatakan sedang dengan perolehan rata-rata nilai 55,71 yang apabila dikaitkan pada penentuan kriteria rata-rata nilai dari PAP dapat dikatakan bahwa tingkat membaca pemahaman kritis siswa SMA Kabupaten Lamongan adalah rendah.

d. Tingkat membaca pemahaman kreatif siswa SMA Kabupaten Lamongan dinyatakan sangat rendah 


Kredo 4 (2020)
KREDO: Jurnal Ilmiah Bahasa dan Sastra
Terakreditasi Sinta 4 berdasarkan Keputusan Direktorat
Jenderal Penguatan Riset dan Pengembangan,
Kementerian Riset, Teknologi dan Pendidikan Tinggi
Republik Indonesia
Nomor: 23/E/KPT/2019. 08 Agustus 2019
https://jurnal.umk.ac.id/index.php/kredo/index

dengan perolehan rata-rata nilai 33 , 5 yang apabila dikaitkan pada penentuan kriteria rata-rata nilai dari PAP dapat dikatakan bahwa tingkat membaca pemahaman kreatif siswa SMA Kabupaten Lamongan adalah sangat rendah.

Tingkat membaca pemahaman siswa SMA di Kabupaten Lamongan secara keseluruhan mencapai 48.62 yang apabila dikaitkan pada penentuan kriteria rata-rata nilai dari PAP dapat dikatakan bahwa tingkat membaca pemahaman siswa SMA Kabupaten Lamongan adalah sangat rendah

\section{SARAN}

Dari hasil penelitian yang telah diuraikan di atas, terdapat beberapa saran untuk meningkatkan kualitas pendidikan dan kemampuan membaca pemahaman siswa SMA. Beberapa saran tersebut sebagai berikut. a. Pemerintah Kabupaten Lamongan, terutama Dinas Pendidikan Kabupaten Lamongan, sebaiknya melakukan pemetaan tingkat membaca pemahaman dan tingkat berpikir siswa agar kemampuan berpikir siswa SMA di Kabupaten Lamongan dapat terkontrol.

b. Pemerintah Kabupaten Lamongan, terutama Dinas Pendidikan Kabupaten Lamongan, sebaiknya melakukan kegiatan atau program untuk membiasakan kegiatan membaca siswa agar kemampuan membaca siswa menjadi baik.

c. Kepala SMA di Kabupetan Lamongan sebaiknya membuat dan menerapkan program literasi sekolah agar siswa terbiasa untuk membaca sehingga budaya membaca di sekolah menjadi sangat tinggi yang dampaknya adalah pada peningkatan kemampuan membaca siswa.

\section{DAFTAR PUSTAKA}

Ardika, I. W. D., Sitawati, A. R., \& Suciani, N. K. (2017). Fenomena Pokok Pendidikan Indonesia: Apa dan Bagaimana?. Soshum: Jurnal Sosial dan Humaniora, 3(1), 96.

Arikunto, Suharsimi. 2010. Prosedur Penelitian: Suatu Pendekatan Praktik. Jakarta: Rineka Cipta.

Gunawan, Imam dan Palupi, Anggraeni Retno. 2012. Taksonomi Bloom—Revisi Ranah Kognitif: Kerangka Landasan untuk Pembelajaran, Pengajaran, dan Penilaian. Premiere Educandum: Jurnal Pendidikan Dasar dan Pembelajaran. Vol. 2. No. 2. $98-117$.

Hairuddin, dkk. 2007. Pembelajaran bahasa Indonesia. Direktorat Jenderal Pendidikan Tinggi Departemen Pendidikan Nasional. 


Kredo 4 (2020)
KREDO: Jurnal Ilmiah Bahasa dan Sastra
Terakreditasi Sinta 4 berdasarkan Keputusan Direktorat
Jenderal Penguatan Riset dan Pengembangan,
Kementerian Riset, Teknologi dan Pendidikan Tinggi
Republik Indonesia
Nomor: 23/E/KPT/2019. 08 Agustus 2019
https://jurnal.umk.ac.id/index.php/kredo/index

Kemendikbud, 2016. Panduan Gerakan Literasi Sekolah. Jakarta: Direktorat Jenderal Pendidikan Dasar dan Menengah.

Kholiq, Abdul. 2018. Tingkat Membaca Pemahaman Siswa SMAN 1 Bluluk Lamongan. Jurnal Reforma. Vol 7, No 1. Hlm. 1-11

Laila, N. A. 2009. Pengaruh Pendekatan CTL (Contextual Teaching and Learning) terhadap Hasil Belajar Membaca Pemahaman Bahasa Indonesia Siswa Kelas IV SD. Cakrawala Pendidikan, (3), 238-248.

Laily, I. F. (2014). Hubungan Kemampuan Membaca Pemahaman dengan Kemampuan Memahami Soal Cerita Matematika Sekolah Dasar. Eduma: Mathematics Education Learning and Teaching, 3(1).

Lamb, R. and Arnold, P. 1975. Reading: Foundations and instructional strategies. Wiltshire: Wadsworth Pub. Co.

Muis, S. F. 2013. Kemampuan Membaca Pemahaman Literal dan Interpretatif melalui Pendekatan Konstruktivisme. Al-MUNZIR, 6(2).

Nurgiyantoro, Burhan. 2001. Penilaian dalam Pengajaran Bahasa dan Sastra. Yogyakarta: BPFE

Nurhadi. 1987. Kapita selekta kajian bahasa, sastra, dan pengajaran. Malang: Jurusan Pendidikan Bahasa dan Sastra Indonesia FPBS-IKIP Malang.

OECD. (2019). PISA 2018 Results Vol III: What School Life Means for Students' Lives. 2019 (Vol. III). Paris: OECD Publishing. https://doi.org/10.1787/acd78851-en

Somadayo, Samsu. 2011. Strategi dan Teknik Pembelajaran Membaca. Yogyakarta: Graha Ilmu.

Sulikhah, S., Utomo, S., \& Santoso, S. (2020). Pengaruh Teknik Survey Question Read Reflect Recite Review (SQ4R) dan Teknik Skema Terhadap Kemampuan Membaca Pemahaman Mata Pelajaran Bahasa Indonesia Pada Siswa Sd Negeri Kelas III di Kecamatan Karanganyar Demak. KREDO: Jurnal Ilmiah Bahasa dan Sastra, 3(2), 365-385.

Tarigan, Henry Guntur. 1986. Teknik Pengajaran Keterampilan Berbahasa. Bandung: Angkasa 